\title{
6
}

\section{THE AIR WAR IN KOREA Coalition air power in the context of limited war}

\author{
Richard Hallion
}

The Korean air war constituted the last significant non-air-refuelled air war, and this created a major problem at the war's outset for those seeking to employ air power effectively in South Korea's defence. While the air-refuelling issue did not strongly influence United States Air Force (USAF) bomber operations, it had a profound impact upon the USAF's tactical air power application, particularly after the North Korean People's Army (NKPA) had overrun most of South Korea's airfields. As a result, naval aviation power projection from carriers was essential in preventing communist forces from completely overrunning the Korean Peninsula. Air superiority operations, including air-to-air defence intercepts, offensive fighter sweeps and airfield attacks, effectively removed the North Korean People's Army Air Force (NKPAAF) as a significant factor in the war by the beginning of July 1950, permitting, in effect, uninterrupted coalition air power operations from then until the intervention of the Soviet air force (the Voenno-Vozdushnye Sily; VVS) in November. Until then, medium and heavy bombers were able to operate essentially from the onset of the war without significant opposition, all the way up to the Manchurian border. 
Operations early in the war were aided as well by North Korea's lack (remedied subsequently) of medium and heavy anti-aircraft artillery. As a result, the combination of available air power forces on land and at sea in the summer of 1950 offset the South's lack of large, in-place, landpower armour and infantry forces, and furnished close air support (CAS) and battlefield air interdiction (BAI). CAS-BAI dramatically reduced the amount of fuel and food available to advancing NKPA forces; destroyed large numbers of vehicles and troops; eased the pressure on coalition landwarfare forces; and substituted for the coalition's own lack of artillery and heavy fire support, particularly during bitter fighting around the Pusan Perimeter and at the Naktong River in August-September 1950. Halting the North Korean advance bought time for reinforcement, reconstitution and the build-up to the invasion of Inchon, the necessary prelude for the subsequent United Nations advance up the Korean Peninsula.

When Mao sent the People's Liberation Army (PLA)—renamed the 'Chinese People's Volunteers Force' (CPVF)—into North Korea in November 1950, this same combination of air-power forces again proved crucially important. Air force fighter operations kept $\mathrm{MiG}$ depredations to a minimum, pending arrival in theatre of the North American F-86 Sabre. Strategic bombers, medium bombers and naval attack aircraft struck at bridge, road and rail targets (although many bridges were dropped, there was alas something of a 'closing the barn door after the horse has bolted' quality to much of these actions). In this crisis, the airmen of the United States Navy (USN) and United States Marine Corps (USMC) again distinguished themselves in ensuring the safe extraction of UN forces and refugees from the port of Hungnam, and covering the withdrawal of Marine and coalition units breaking out from the Chosin Reservoir. Afterwards, land- and sea-based air power functioned much as it had six months earlier (although with far better coordination and organisation), again with steady attrition of advancing CPVF forces, to the frustration of the PLA's Korean leadership and troop-level cadres. After the war stabilised along a relatively static Main Line of Resistance (MLR) in 1951, land-and sea-based air power forces furnished persistent observation, surveillance, reconnaissance, interdiction, battlefield air attack, CAS and artillery and naval gunfire control until the Korean armistice in July 1953. 


\section{Military aviation, $1945-53$}

The two great revolutions that transformed aviation at mid-century were the development of the jet engine and the derivation of high-speed aerodynamic design theory (typified by the swept-back wing), which enabled flight at speeds approaching and exceeding the velocity of sound. Both promised, and then made possible, the era of 600-plus miles per hour (960-plus kilometres per hour) flight speeds. However, integrating the jet aircraft into the force structure of leading air-power nations proved difficult and time-consuming. Early turbojet aircraft had very high fuel consumption rates, in contrast to slower, long-loitering propeller-driven designs. Mixing older propeller-driven and newer jet aircraft in common strike packages required creative planning to ensure that the slower aircraft were not left unprotected over a target area, while the faster aircraft did not run out of fuel too soon. (This problem, incidentally, affected both the United Nations Coalition and the VVS and PLAAF in their own air operations, sometimes with disastrous results.) Command and control of the new jet aircraft posed its own problems, for ground controllers were used to the behaviour of petrol-fuelled, piston-powered aircraft, not kerosene-guzzling jets. As one fighter test pilot recalled, controllers 'did not understand how altitude affected range and endurance. We pilots measured fuel in pounds and minutes, and the controllers measured it in gallons and hours. We would climb to 35,000 feet, and they would vector us to intercept a bogey at sea level and then wonder why we never had enough fuel'. ${ }^{1}$

Operating from land bases, the USAF had less difficulty adapting to the jet age, but even so, the peculiarities of early generation jet engines took a high operational toll on pilots. This stemmed particularly from the engines' low-thrust and slow throttle-response (reflecting slow spool-up time, or rotative acceleration), leaving aircraft with a generally sluggish slow-speed performance. Exacerbating this were the low-speed aerodynamic deficiencies of early swept-wings, which lacked the liftenhancing technologies available to later aircraft. Both the Soviet MiG-15 and North American F-86 possessed vicious deficiencies in their handling qualities that could bite the unwary with a vengeance.

1 D.D. Engen, Wings and Warriors: My Life as a Naval Aviator, Smithsonian Institution Press, Washington, DC, 1997, p. 102. 
Integrating jet aircraft into an operational construct was a particular challenge for naval aviation. Early jet aircraft lacked the rapid throttleresponse characteristics of propeller-driven aircraft, and had nowhere near the rapid throttle transient characteristics of later fighter aircraft such as the F-15 and F/A-18. Their lower-aspect-ratio wings (a concession for speed) endowed them with higher sink rates (rate of descent) than their propeller-driven, higher-aspect-ratio predecessors. Only after Korea did the USN introduce swept-wing fighter aircraft into operational service. The Royal Navy's Fleet Air Arm and France's Aéronavale introduced them even later. Thus, the US Navy fought Korea with straight-wing jet aircraft, typified by its Grumman F9F Panther. While these were more than adequate to deal with the NKPAAF's propeller-driven Yak fighters in the summer of 1950, the Panther was seriously outclassed by the Soviet-flown swept-wing MiG-15 when it appeared in Korean skies in November 1950. So too was the straight-wing, twin-engine McDonnell F2H Banshee. Fortunately, the quality of naval pilots was such that, oneon-one, USN airmen generally evaded opposing MiG fighters, and in some cases shot them down.

The safety statistics for both the USAF and US Navy in the 1940s and 1950s reveal the very high loss rates associated with early jet aircraft operations. During the Korean War, the USAF lost 787 aircraft to enemy action and 960 others in non-combat losses: 1,747 aircraft, or approximately one lost per 456 sorties. In the same time period, the US Navy and US Marines lost 567 aircraft in combat and 684 in non-combat losses: 1,251 aircraft, or approximately one lost per 240 sorties. Naval aviation was thus almost twice as dangerous as land-based aviation, largely an indication of the inadequacies of both the straight-deck carrier in the early jet era and of the turbojet aircraft that operated from it. As an example of naval loss rates in Korea, the carrier USS Essex went to war in August 1951: less than a month later it returned to Japan, having lost 18 aircraft (more than 20 per cent of its air group), eight aircrew and seven maintainers, including one horrendous deck-landing accident that killed eight, injured 16 and destroyed four aircraft. ${ }^{2}$

Then there were basic problems with combat execution owing to the erosion of skills after the Second World War. In January 1949, all of the USAF Strategic Air Command's bombers flew against Dayton, Ohio,

2 Essex action report, 8 August-21 September 1951, pp. 2-4, Naval History and Heritage Command archives, Washington Navy Yard, Washington, DC. 
practising bombing from 30,000 feet: analysis indicated that, if they had actually dropped bombs, the average bomb would have hit 10,090 feet (more than 3 kilometres) from the aim point. About the same time, a naval Corsair squadron in Seattle flew cross-country to visit another in Denver. None of its pilots managed to find Denver, instead landing in twos and threes across various states. For a service that had routinely sent its fighter pilots out from carriers against enemy fleets and shore targets, it was, as one naval officer characterised it, 'beyond belief'. ${ }^{3}$

Oddly enough, and as touched on in an earlier chapter, the greatest threat to UN air superiority in Korea-the MiG-15-owed a considerable debt to Great Britain. In 1946, Britain sold 55 Rolls-Royce Derwent and Nene jet engines to the Soviet Union, a controversial decision that ANU historian Joan Beaumont judged as 'manifestly against Great Britain's and the West's strategic interests'. ${ }^{4}$ (Allegedly, Stalin wondered aloud: 'Who's stupid enough to sell his secrets?'5) Both the Derwent and Nene were reverse-engineered and placed into production for use in new Soviet jet fighters and bombers. ${ }^{6}$ At that time, the Royal Air Force (RAF) did not possess any operational swept-wing aircraft of its own. Instead, its finest fighter was the subsonic straight-wing, twin-engine Gloster Meteor F.8, 94 of which the Royal Australian Air Force (RAAF) received in 1951 as replacements for the RAAF's even more obsolescent propeller-driven Mustangs. ${ }^{7}$

Then there was the state of air power on the Korean Peninsula. Military ties with the United States were ostensibly strengthened in 1948, but excluded air power. At a time when the Democratic People's Republic of Korea (DPRK) gained a surprisingly robust air arm of more than 160 propeller-driven fighters and attack bombers, the Republic of Korea (ROK) was allowed just a token air service less than a tenth the size of North Korea's. It consisted of 13 light, fabric-covered Piper L-4

3 A.S. Crossfield with C. Blair, Always Another Dawn, World Publishing Co., Cleveland, 1960, p. 117; he was one of the pilots involved.

4 J. Beaumont, 'Trade, strategy, and foreign policy in conflict: The Rolls-Royce affair 1946-1947', International History Review 2, no. 4, 1980, pp. 603, 616.

5 Y. Gordon, Early Soviet Jet Bombers, Midland Publishing, Hinckley, Leicestershire, 2004, p. 4.

6 A.S. Yakovlev, Fifty Years of Soviet Aircraft Construction, NASA TTF-627, Israel Program for Scientific Translations \& National Aeronautics and Space Administration, Jerusalem, 1970, pp. 103-4. Klimov design bureau engineers so closely copied the Nene that, after inspecting one, its designer, Sir Stanley Hooker, remarked, 'They even copied the mistakes!'

7 A. Stephens, Going Solo: The Royal Australian Air Force, 1946-1971, AGPS, Canberra, 1995, pp. 229-32. 
and Stinson L-5 liaison aircraft and three North American T-6 trainers, offering no combat capability whatsoever. So muddled was US policy over the future of South Korea and its air capabilities that President Syngman Rhee sought the advice of retired Major General Claire L. Chennault on forming a force like the Flying Tigers-American volunteers who flew in China in 1941-42 under Chennault's command. He responded by crafting a plan for a 99-plane force built around a core of F-51 Mustangs, but it did not come to pass. The last US military forces left Korea at the end of June 1949. Six months later, Secretary of State Dean Acheson artlessly explained the United States' perception of its security responsibilities in the western Pacific, seemingly consigning South Korea to a zone beyond US interests. Six months after that, North Korean tanks rumbled across the arbitrary line separating the two Koreas, launching an outright invasion of the South.

\section{Air power at war}

For airmen, Korea was a war of many images: the MiG v. Sabre duels in what became known as 'MiG Alley'; the day-to-day routine of interdiction, air pressure and CAS strikes; the night strategic bombing war and the night-fighter crews of the US Marine Corps, US Navy and Far East Air Forces (FEAF) that supported it; and the operations at sea of the USN's Task Force 77 (TF77) and the light carrier forces. Often neglected but crucially important were maritime patrol operations that watched for communist submarine forces and North Korean mine-layers. Here, too, it was a coalition effort, with three RAF Sunderland squadrons partnered with the 'patrons' (patrol squadrons) of the USN. Helicopter crews earned special respect for their 'can do' attitude and willingness to take rudimentary and woefully underpowered and underprotected craft into enemy territory.

Crucial to the conduct of combat operations in Korea was control of the air. Overall, the UN coalition began the war with air parity, moved rapidly to assert air superiority and never lost that superiority over the duration of the conflict. But the story is more complex than that. In the fall of 1950, the introduction of the MiG-15 and their Soviet pilots dramatically transformed the air war. Only its short range (in its initial models) and the Stalin-prescribed policy that the Soviet air force, the VVS, limit its operations to MiG Alley prevented the MiG from having an 
even greater influence. It immediately rendered obsolete all other fighter aircraft in theatre. Had the quality of its pilots been up to that of the UN coalition-and some MiG pilots were quite experienced-the impact on UN operations would have been extraordinary. If the communist air leadership had succeeded in persuading the Soviet Union to allow the VVS to take a greater role over North Korea, the battle for air control could have moved south to the Main Line of Resistance (MLR) and east and west to the coastal waters of Korea, denying FEAF and naval aviation forces much of the freedom they enjoyed to conduct routine operations so close to hostile territory.

Undoubtedly the coalition benefited from the availability of the F-86 Sabre in its swept-wing platform. The Sabre was far from a perfect fighter aircraft, but it had sufficient advances to enable it to dominate the MiG-15 in the high-speed arena, thanks largely to a better flight control system and better basic aerodynamics. The MiG-15's tendency to enter unrecoverable spins seriously constrained its combat utility: in 32 observed combat spins, 29 of the MiGs involved continued spinning into the ground. ${ }^{8}$ A flight test evaluation on a NKPAAF defector's MiG, delivered to Kimpo after the war, confirmed the Sabre's basic superiority over it, but noted as well other aspects in which the MiG's performance, particularly its acceleration, was better. Overall, the USAF credited the F-86 with shooting down $810 \mathrm{MiGs}$ for the loss of 78 Sabres, a victory-to-loss ratio of more than 10:1. In the years since, the merit of this number (and the 14:1 ratio for experienced Sabre pilots against tyros with new VVS or PLAAF units) has been hotly debated. Undoubtedly, as in any air war, both sides engaged in overclaiming, usually a result of misinterpreting what one sees happening at the time. In any case, many aircraft (on both sides) carried as operational losses because of disappearances or other unexplained losses were in any case lost on air combat operations. Certainly the Sabres performed at far better than air parity, and to this author, a victory-to-loss ratio of about 8:1 seems a completely reasonable figure.

Even so, it must be noted that the F-86, for all its merits, was hard pressed, particularly as its early models lacked the power (and hence thrust-to-weight ratio) one would have desired in a transonic jet fighter. RAF Squadron Leader William 'Paddy' Harbison, an experienced fighter pilot, MiG-killer and noted fighter tactician, was sent to Korea in February

8 W.T. Y'Blood, MiG Alley, Air Force History and Museums Program, Washington, DC, 2000, p. 38. 
1952 and flew combat missions with the 4th Fighter Wing. His classified comparative study concluded: 'The relative superiority of the present F-86E pilot-plane-weapon "team" is not likely to continue forever. In point of fact, it is the considered opinion of most pilots that, given the present MiG-15 advantages of combat location, the rising proficiency of the MiG-15 "team" will eventually void our present superiority." In fact, the USAF introduced the F-86F, and it retained its dominance over the MiG-15 to the end of the war.

But the air war over MiG Alley was far from a sure thing. Brigadier General Michael De Armond recalled in 2000: 'At times it was pretty grim ... I don't want you to think that we stood back there and knocked the MiGs down out of the sky without losing a lot of very, very good people. ${ }^{10}$ Harbison was quite correct that the moment of the Sabre's superiority over the MiG-15 was passing. It is interesting to contemplate what might have happened, had the air war continued into 1954, if the MiG-15 force in Korea was augmented, then replaced, by the later MiG-17. Deceptively similar to the early MiG-15 in appearance, the MiG-17 totally outclassed the F-86F, and would have been at worst equivalent to the slightly later $\mathrm{F}-86 \mathrm{H}$.

Achieving and holding air superiority was primarily the responsibility of the USAF, as the USN and coalition air forces lacked an aircraft equal to the MiG-15 and the F-86 until after the war. Nonetheless, those forces played a role in the battle for control of Korea's skies. TF77's F9F and F2H Panther pilots provided top cover for B-29 bombing strikes going to the far north of Korea near the Soviet frontier, and routinely provided cover for their fellow naval aviators on strikes on the periphery of, or into, MiG Alley. As well, they capped the fleet; that is, they provided combat air patrol cover for naval assets. Early in the afternoon of 18 November 1952, at least seven VVS MiGs left an airfield near Vladivostok and flew on a direct course towards TF77, attacking four F9F-5s, the latest and most powerful model of the veteran Panther. The superior training of the navy

9 Sqdn Ldr W. Harbison, The F86 v. the MiG-15, RAF Central Fighter Establishment, West Raynham, Norfolk, 1952, AIR 8/1709, National Archives, Kew, Great Britain [TNA]. I thank retired RAF Air Vice Marshal Paddy Harbison for his contributions to my understanding of the air war over North Korea.

10 Statement of DeArmond in Silver Wings, Golden Valor: The USAF Remembers Korea, ed. R.P. Hallion, USAF, Washington, DC, 2006, p. 34. DeArmond was shot down and taken prisoner in the war. 
airmen, and the better gunsight and gun system of the F9F-5, saved them from loss; three (perhaps four) MiGs were shot down at the price of one Panther seriously damaged. VVS airmen never again approached TF77.

The RAAF pitted its Meteor F.8 fighters (which had replaced No. 77 Squadron's Mustangs in early 1951) against the MiG, losing four but shooting down five MiGs in return. The Marines furnished Yalu patrols for B-29 night strikes, shooting down several MiG-15s with their Douglas F3D-2 Skyknights. The US Navy and Marines teamed to furnish air defence for Kimpo, Seoul and other South Korean advanced locations, which came under extensive heckling attacks by Korean People's Army Air Force Polikarpov Po-2, Yak-18 and legacy ex-Imperial Japanese Army Air Force Tachikawa Ki-9 light aircraft; one Corsair pilot received credit for five victories over the annoying little attackers.

\section{The air-to-ground war}

The single most controversial aspect of Korean air operations was the conduct of close air support (CAS) in the first year of the war. By late July it seemed possible that UN forces would be thrown off the peninsula by an army that had not even existed five years previously. At the heart of the problem was that, while joint terminology defined 'close tactical air support' as 'air action against hostile surface targets which are so close to friendly forces as to require detailed integration of each air mission with the fire and movement of these forces', there was no agreed joint operating doctrine covering such operations. Instead, the marines and the navy had developed one system and the army and the air force another, each to achieve different ends.

Mirroring their origins as a lightly equipped landing force, the US Marines employed their aircraft as a substitute for battlefield artillery. The USMC-USN system delivered CAS from the line of contact back to the artillery line, similar to Great War trench strafing. ${ }^{11}$ The army had a layered support system, rooted in army and air force experience gained in air-land operations during the breakout across France in 1944. ${ }^{12}$ Army

11 A. Millett, 'Korea, 1950-1953', in Case Studies in the Development of Close Air Support, ed. B.F. Cooling, USAF, Washington, DC, 1990, pp. 345-410; and P.B. Mersky, US Marine Corps Aviation: 1912 to the Present, Nautical and Aviation Publishing Company of America, Annapolis, MD, 1983. 12 D.N. Spires, Air Power for Patton's Army: The XIXth Tactical Air Command in the Second World War, USAF, Washington, DC, 2002. 
doctrine granted both land and air commanders equal authority in setting priorities for tactical air support, and carved out an artillery-only zone in front of the line of contact, extending back approximately 1,000 metres to a so-called artillery line. This ensured that army artillery could freely engage enemy forces unhindered by air force air support aircraft. ${ }^{13}$ Thus, the USAF would not routinely deliver air support inside the artillery line. Beyond the artillery line, the army-USAF system allowed coordinated air support from the artillery line to an army-designated bomb line. While both the army and the air force then defined this as CAS, it was, to use more recent parlance, battlefield air interdiction (BAI). Working together, both systems furnished complementary coverage that denied any area of sanctuary for the foe, from the line of contact to the bomb line, and air operations beyond the bomb line extended that zone of vulnerability across the enemy's rear areas.

The CAS challenge became acute in August and early September 1950, as NKPA forces closed in on the contracting Pusan Perimeter. USMC Corsair pilots flew their first CAS missions from the carrier USS Sicily on 3 August, the beginning of a particularly acute period in the fight to save South Korea. Here the doctrinal, equipment, training and exercise shortfalls of the postwar period took their greatest toll, for combat operations quickly revealed numerous deficiencies, particularly a lack of effective communication. Maps lacked the proper grid references to ensure accurate positional reference. Serious deficiencies, incompatibilities and differences existed among the services' communication systems. Inadequate ship-to-shore circuits hindered communication between TF77 and Fifth Air Force. Korea's hilly terrain and old equipment limited the ability of army-USAF tactical air control party radio jeeps to communicate with strike aircraft. In the air, things were somewhat better, as USAF and Marine forward area controllers had modern multichannel radios, but poor radio discipline and extraneous chatter saturated the net.

13 USA, Air-Ground Operations: Field Manual, War Department, Washington, DC, 1946, pp. 31-5; W.T. Y'Blood, Down in the Weeds: Close Air Support in Korea, USAF, Washington, DC, 2002; W.T. and B.C. Nalty, Within Limits: The USAF and the Korean War, USAF, Washington, DC, 1996. M. Lewis, Lt Gen. Ned Almond, USA: A Ground Commander's Conflicting View with Airmen over CAS Doctrine and Employment, School of Advanced Air Power Studies, Air University, Maxwell AFB, June 1996. 
In August, nearly 30 per cent of all navy CAS sorties were cancelled because pilots could not contact controllers. ${ }^{14}$ Carrier commander Admiral John Thach recalled years later, 'The pilots would come back and say, "We couldn't help. We wanted to. We were there and we couldn't get in communication with people."' 15 Fortunately, this changed over time, but until it did, many pilots took off on solo 'road recce' missions in search of targets, which, at this point in the war, were relatively plentiful. 'A typical two-aircraft combat recce flight,' one recalled subsequently, 'would yield three or four trucks, a bus, and perhaps a locomotive.'16

However imperfect, the two competing CAS systems first caused attrition to, then blunted, then halted the North Korean advance, often inflicting hundreds of casualties, particularly if used against massed-formation infantry attacks. By mid-August, the NKPA advance came to a halt along the Naktong River, stopped by the resolute defenders of the Pusan Perimeter and by the combination of deep air attack, robbing NKPA forces of food, fuel and ammunition, and battlefield air attacks supporting ground defenders.

By now the steady supply attrition caused by the Far East Air Force's (FEAF) bridge-bombing campaign had inflicted serious shortages in the NKPA forces. For the period between 25 June and 1 November 1950, 21 per cent of NKPA prisoners attributed their low morale to lack of food (a product of both air strikes on northern supply lines and a local famine in the South), while another 18 per cent attributed it to fear of aircraft attack. Battlefield air interdiction, by dropping bridges, destroying vehicles and forcing movement at night, greatly hindered supply of front-line NKPA forces, whose individual food ration fell from 800 grams per soldier per day at the onset of the war to just 400 grams (primarily rice) by the time the NKPA advance stopped at the Naktong. Rail strikes so disrupted transport that it took a month for reinforcements to journey from Pyongyang to the Pusan front, moving at an average slightly less than 10 miles (16 kilometres) per day, as trains hid in tunnels during the day. ${ }^{17}$

14 US Pacific Fleet Operations Comander in Chief US Pacific Interim Evluation Report No. 1: 25 June-15 November 1950, www.history.navy.mil/research/library/online-reading-room/title-listalphabetically/k/Korean-War-Interim-Evaluation-No1.html.

15 Admiral John S. Thach, USN (retd), interview with Cmdr Etta-Belle Kitchen, US Naval Institute Oral History Program, p. 533; copy of transcript in US Naval Academy Library, Annapolis, MD; see also USN, Interim evaluation report no. 1, vol. 3.

16 Engen, Wings and Warriors, p. 116.

17 E. Mark, Aerial Interdiction: Air Power and the Land Battle in Three American Wars, USAF, Washington, DC, 1994, pp. 280-2. 
Truck losses caused particular concern because they engendered cascading effects, including shortages of food, ammunition and fuel, that triggered problems in morale, fitness and combat effectiveness. The 'high casualty rate among truck drivers led to numerous desertions', one analyst noted; the NKPA resorted to forcing prisoners to drive their trucks. Ordnance and ammunition shortages grew as the average tonnage delivered to NKPA divisions dropped from 166 tons per day in late June 1950 to just 17 tons per day in mid-September. ${ }^{18}$ Although it tried, the NKPA could not resume its offensive.

On 15 September 1950 General Douglas MacArthur oversaw the Inchon landing, the largest amphibious operation since the Second World War. In the two weeks of Inchon-related operations, the UN air coalition, spearheaded by naval air power but supported as well by FEAF interdiction attacks, coalition air attacks and aerial supply by FEAF's Combat Cargo Command, furnished protection, direct attack, indirect support and logistical assistance. Further south at Pusan, a similar air assemblage accomplished the same for the Eighth Army. Withdrawing NKPA forces both at Inchon-Seoul and at Pusan were mercilessly bombed, strafed, rocketed and napalmed by near-constant air attacks that took a fearsome toll of NKPA forces. Air attacks along the Naktong killed thousands, including 1,200 in a single strike on NKPA soldiers attempting to cross the river. ${ }^{19}$ Afterwards, the NKPA was in headlong retreat.

Having broken out, the US Eighth Army advanced north from Pusan and linked up with X Corps near Osan. Both moved north, crossing the pre-war border, overrunning both the North Korean capital at Pyongyang (thereby forcing Kim Il Sung to decamp for Sinuiju on the Yalu River across from Andong) and the strategic port of Wonsan. As the bomb line moved north towards the Yalu, so too did the air campaign.

\section{Halt phase redux}

Unknown to MacArthur and his commanders, as revealed earlier, three Chinese armies under General Peng Dehuai had already crossed into North Korea, and three more were on the way, encouraged by the expectation that, unlike the North Koreans earlier, they would receive active air

18 USAF HD, USAF Operations in the Korean Conflict, 25 June-1 November 1950, p. 46.

19 Futrell, USAF in Korea, p. 162. 
support from the Soviet air force, the VVS. (Stalin, as Xiaoming Zhang has noted, 'never intended to offer the support the Chinese expected' ${ }^{20}$ ) In late October, isolated captures of Chinese soldiers occurred on the US Eighth Army's front. Alarmed, MacArthur ordered airmen to sever the Yalu River bridges linking North Korea to Manchuria. FEAF Bomber Command's B-29s and TF77's Douglas AD-4 Skyraider aircraft took on the task. The first B-29 raid, launched on 8 November against Sinuiju's bridges and the city itself, failed to drop any spans; but the bombers burned out 60 per cent of the city, killing 2,000, and shocking a group of visiting VVS generals watching from across the river at Andong. During the B-29 strike, MiGs attacked its F-80C escort. In the dogfight that followed, the air force claimed its first victory over the speedy Soviet jet. The next day, navy pilots shot down another, marking the first aerial victories over the $\mathrm{MiG}$.

Air force and navy bridge attacks ultimately dropped five bridges in total, but to little immediate effect, as approximately 180,000 Chinese People's Volunteers (CPVF) had already crossed into North Korea. On 25 November, Peng Dehuai launched a devastating assault against the US Eighth Army in the west; the next day his troops attacked the US X Corps in the east. By 28 November, MacArthur's invasion forces were in retreat, triggering an emergency need for tactical air support. ${ }^{21}$ Interdiction and continued bridge attacks assumed greater importance in an effort (largely successful, in contrast to popular myth, as will be discussed) to rob CPVF forces of sustenance, matériel and firepower. In the west, the US Eighth Army collapsed so rapidly that Peng could not press his advantage, but eastern Korea was potentially far more disastrous. The burden of covering that withdrawal fell to just two USN carrier air wings, one carrier-deployed USMC Corsair squadron, and USMC air ashore (i.e. an air unit based on shore), supported by USAF and coalition airlift for supply and casualty evacuation.

On 1 December, the Marines began their breakout. It is likely that the Marine withdrawal would have ended in disaster except for the efforts of naval and USMC airmen, who flew a total of 2,200 CAS-BAI sorties from

20 Xiaoming Zhang, Red Wings Over the Yalu: China, the Soviet Union, and the Air War in Korea, Texas A\&M University Press, College Station, TX, 2002, p. 73.

21 D. McCullough, Truman, Simon \& Schuster, New York, 1992, pp. 817-22; see also S.L.A. Marshall, The River and the Gauntlet: Defeat of the Eighth Army by the Chinese Communist Forces, November 1950, in the Battle of the Chongchon River, Korea, William Morrow \& Co., New York, 1953, which relates the collapse in harrowing detail; and Zhang, Red Wings Over the Yalu, pp. 91-2. 
1 to 11 December, furnishing 24-hour air support. ${ }^{22}$ Coalition airlifters evacuated more than 1,800 seriously wounded Marines from Hagaru-ri and Koto-ri, and an intense USAF-USMC air supply and airdrop effort kept the Marines supplied-including bridge sections so that a crucial bridge could be repaired, permitting the Marines to withdraw their vehicles, many laden with wounded and weary troops. The Marine column linked up with Marine reinforcements from the coast on 10 December, and arrived safely at Hamhung the next day. ${ }^{23}$ The withdrawal had been costly, with 718 dead and many more wounded or incapacitated by frostbite and other injury, but it could have been far worse. Battlefield air support devastated CPVF forces. The USAF introduced the swept-wing F-86A into combat on 15 December, and two days later, it claimed its first MiG-15. With the introduction of the F-86A, the USAF redressed the technological disparity. While the UN coalition would never be able to claim that it had air supremacy over the entire Korean Peninsula, it clearly possessed it over the main line of resistance between NKPA, CPVF and UN forces. ${ }^{24}$

As the CPVF made their way south, constant UN air attack took a steady toll, and as its effects grew more pronounced, so too did Peng's pleas to Mao for help. (In response, Mao urged him onwards with vague promises of possible Soviet air support that never came.) The CPVF forced the UN coalition back, but could not achieve a breakthrough, taking fearsome casualties, one of whom was Mao's own son, killed in an air strike. By the end of January 1951, the front had stabilised in a rough line running from south of Osan in the west, to a point south of Samchok in the east. A frustrated Peng returned to China, complaining to Mao that air attacks had limited his forces to receiving only 30 per cent of what they needed to prosecute an offensive. Peng's deputy commander, General Hong Xuezhi, reported combined air attack and artillery robbed the CPVF of 43 per cent of its trucks. ${ }^{25}$ Prisoner interrogations indicated that CPVF soldiers were surprised at the strength of UN air power, had lost faith in their leaders and had lost hope of a CPVF victory. One last offensive

22 K.W. Condit and E.H. Giusti, 'Marine air at the Chosin Reservoir', Marine Corps Gazette 36, no. 7, 1952, pp. 18-25; Giusti and Condit, 'Marine air covers the breakout', Marine Corps Gazette 36, no. 8, 1952, pp. 20-7.

23 W.M. Leary, Anything, Anywhere, Anytime: Combat Cargo in the Korean War, USAF, Washington, DC, 2000, pp. 17-23.

24 The best analysis is K.P. Werrell, Sabres over MiG Alley: The F-86 and the Battle for Air Superiority in Korea, Naval Institute Press, Annapolis, MD, 2005.

25 Mark, Aerial Interdiction, note, pp. 27, 303. 
gambit in late April also proved a failure. Finally, on 24 June, the Soviet Union suggested armistice talks, in recognition that Mao and Kim could not unify the North with the South by military means. ${ }^{26}$

Afterwards, a CPVF study team concluded that, with control of the air, 'we could have driven the enemy into the sea and the protracted defensive battles ranging from 25 January to 22 April ... should have been avoided'. ${ }^{27}$ UN senior commanders concurred. The US Eighth Army's General Walton Walker stated, 'Had it not been for the outstanding work of the Air Forces, we would most certainly have been pushed out of Korea'. ${ }^{28}$ Although generally an air sceptic, General Matthew Ridgway (who replaced Walker as the Eighth's commander) agreed, writing years later, 'Not only did air power save us from disaster, but without it the mission of the United Nations forces could not have been accomplished'. ${ }^{29}$

\section{Interdiction, air pressure and the path to armistice}

With the CPVF and its supporting NKPA elements stopped, the United Nations turned to regaining lost ground, establishing a MLR, with fortifications and trench works echoing the Great War, running diagonally north-east from Munsan in the west to Kosong in the east. As armistice talks commenced and progressed, Sabres and MiGs duelled over the Yalu, and UN airmen undertook a series of interdiction campaigns to rob front-line NKPA-CPVF forces of the food, ammunition and other supplies they required to fight. At the main line of resistance, aroundthe-clock battlefield air support by UN airmen proceeded without fear of communist air intervention.

The greatest dangers facing UN coalition air attackers were large antiaircraft cannon; light flak, predominantly 37-millimetre cannon, and 12.7-millimetre and 7.62-millimetre machine guns; as well as barrage

26 Zhang, Red Wings Over the Yalu, pp. 113-17.

27 Report of the Chinese Special Aviation Group, in USAF, Far East Air Forces intelligence roundup, no. 69, 22-28 December 1951, AFHRA Archives.

28 Futrell, USAF in Korea, p. 146. It is clear, from the context of this and some of his other comments, that his judgement encompassed the contributions of naval aviation and coalition forces. 29 M.B. Ridgway, The Korean War: How we Met the Challenge, How All-out Asian War was Averted, Why Macarthur Was Dismissed, Why Today's War Objectives Must be Limited, Doubleday \& Co., Garden City, NY, 1967, p. 244. 
fire from rifles, machine pistols and carbines. North Korean forces also often strung cables between hills to deter low-level night attackers. In the first six months of 1951, flak shot down 190 UN coalition aircraft, an average of more than one per day. April, coinciding with Peng's last push, was particularly costly; that month, among other losses, cost the UN coalition 30 Corsairs (two-thirds of which were Marine) and 30 F-51s, an indication of the vulnerability of slower, propeller-driven strike aircraft to light anti-aircraft fire. ${ }^{30}$

As fighting continued into the summer of 1951, interdiction operations against supplies assumed top priority, and after 20 September 1951 interdiction assumed such a priority that Far East Air Force removed TF77 from any CAS responsibilities except in tactical emergencies. ${ }^{31}$ Korea's interdiction campaign involved three separate efforts: Operations Strangle I (mid-1951), Strangle II (late 1951) and Saturate (1952). Interdiction largely involved daytime bridge attacks and rail cuts, and hazardous night attacks against trucks and trains moving supplies south. ${ }^{32}$ Bridge attacks undoubtedly discomfited the CPVF-Peng repeatedly complained of the delays and denial of supply they caused-but they were a far greater source of frustration to the UN airmen who attempted to destroy the bridges. As they dropped, the number of work-arounds proliferated, and supplies continued to get through. Results from rail strikes were mixed; by October 1951, attackers were destroying North Korea’s western rail network so rapidly that repair crews could not keep up, forcing North Korean authorities to concentrate on keeping the line from Sinuiju to Pyongyang in service. A month later, all direct lines from Manchuria into central North Korea had been closed, while in the east TF77 had closed rail traffic into Wonsan, forcing communist forces into timeconsuming (and harrowing) journeys. But the proliferation of their antiaircraft artillery and light flak, coupled with the new MiG-15s equipped with range-extending drop tanks, endangered coalition operations north of Pyongyang, reversing this situation. ${ }^{33}$

30 W.H. Rankin, The Man Who Rode the Thunder, Pyramid Books, New York, 1961, pp. 40-66.

31 R.P. Hallion, The Naval Air War in Korea, Nautical and Aviation Publishing Company of America, Baltimore, MD, 1986, p. 92.

32 B. Tillman and J.G. Handelman, 'The Hwachon Dam and Carlson's Canyon: Air Group 19's Princeton Deployment of 1950-51', The Hook 12, no. 1, 1984, pp. 32-7. These attacks have gone down in history as the Battle of Carlson's Canyon. They inspired arguably the greatest combat aviation novel ever written, James Michener's Bridges at Toko-ri, Random House, New York, 1953.

33 Mark, Aerial Interdiction, pp. 312-17. 
Interdiction posed a serious challenge. The fighting from May 1951 was largely positional jockeying along the MLR. Hence the amount of matériel getting through, however slight, was more than sufficient to keep the communist forces well supplied for combat. The targets themselves were not susceptible to nodal damage effects: rail cuts were easily filled in, highway cuts even more so, and bridges often were so low to the ground, or on such flat land, that temporary repairs, detours and pontoon bridges could easily replace them. A rail cut could be typically repaired in a few hours (rarely longer than a day), and bridge cuts often could be bypassed or patched with heavy timber framing. As Eighth Army Commander Lieutenant General James A. Van Fleet (who had succeeded Ridgway) noted after the war, 'We won the battle to knock out the bridge, but we lost the objective, which was to knock out the traffic'. ${ }^{34}$

Night interdiction over Korea's mountainous terrain posed particular challenges. The air force, navy and Marine Corps vigorously prosecuted a night air war, but the hazards of hunting for trains and trucks, then manoeuvring to attack them, posed serious challenges and safety risks. The murky circumstances of night attack led to over-claiming, as bomb and napalm eruptions were mistaken for exploding vehicles and trains. A USAF operational analysis found night intruders were only destroying 1.8 trucks for every 100 bombs they dropped, and strafing accuracy was at best $1-2$ per cent of all rounds fired. ${ }^{35}$ There is no reason to believe that USN and USMC results were any better than those of Far East Air Force.

In the spring of 1952, FEAF's Deputy for Operations, Brigadier General Jacob E. Smart, had prepared a plan for selective air pressure strikes against key North Korean targets, starting with power generation. General Mark Clark (who had become UN forces commander in May) strongly endorsed the plan, ordering Smart and Navy Admiral J.J. 'Jocko' Clark to work together. Their first air pressure strike targeted the Suiho hydroelectric facility on the Yalu with almost 200 US Air Force, Navy and Marine aircraft on 23 June 1952. When the smoke cleared, Suiho was knocked out of the war. Simultaneously, other USN, USAF and Marine attackers hit smaller power generation facilities at Chosin, Fusen and

34 J.A. Van Fleet, Rail Transport and the Winning of Wars, Association of American Railroads, Washington, DC, 1956, p. 35.

35 Mark, Aerial Interdiction, pp. 317-18. 
Kyosen, destroying 90 per cent of North Korea's electrical power grid. ${ }^{36}$ Afterwards, Smart and Clark continued their joint operations, targeting military facilities in and around Pyongyang, then North Korea's extractive and processing industry, including the Sindok lead and zinc mill, a magnesium carbonate plant at Kilchin, a supply centre at Changpyongni, the Aoji oil refinery, industrial and power-plant targets at Munsan and Chongjin, and a rail centre at Kowon. ${ }^{37}$ The air pressure strikes seriously disconcerted the communist leadership and exacerbated growing divisions between the three parties-Soviet, Chinese and North Korean-over what the future course of the war and the proper role of communist air power should be.

In May 1953, the USAF and USMC attacked North Korea's Toksan and Chasan irrigation dams, releasing water that destroyed eight bridges and miles of rail line and roads, flooded ripening rice paddies and rendered at least one airfield unusable. This apparently demoralised North Korea's Kim, already upset at the unwillingness of the Soviet Union and China to defend North Korea's airspace more aggressively, and encouraged his growing desire to bring the conflict to a close. ${ }^{38}$ Fighting continued for a further six weeks, victory being defined for both sides as securing commanding terrain along the MLR.

In the fighting from the fall of 1952 through the armistice, the tempo of the ground war gradually increased, as both sides jockeyed for favourable position. The interdiction campaign had until then proved a disappointment, as the relatively low level of communist logistical expenditure meant that the losses inflicted upon the NKPA and the CPVF were not enough to have much influence. But now that changed, for the ammunition and supply demands of the NKPA and CPVF gradually rose as well.

In May 1953, Jocko Clark made a familiarisation flight along the front, just behind the line of contact and out of reach of enemy anti-aircraft fire. As he overflew allied supply areas, located out of reach of communist

36 Quote from Naval History and Heritage Command, 'Korean Combat Action Reports for USS Boxer (CV/CVA 21)', 9 June-8 July 1952, p. 5; for raid, see Futrell, USAF in Korea, pp. 449-52, and Zhang, Red Wings Over the Yalu, p. 188.

37 Futrell, USAF in Korea, p. 495; see also Cagle and Manson, Sea War in Korea; and Naval History and Heritage Command, 'Korean Combat Action Reports for USS Essex (CV/CVA 9)', 5 September-1 November 1952, pp. 1-2.

38 Zhang, Red Wings Over the Yalu, p. 197. 
artillery, he realised that if the communists had had the ability to project air power over the front, such open storage would have been impossible. But the NKPA and CPVF had to have large caches of supplies at the front, simply to sustain the pace of day-to-day artillery barrages and savage infantry assaults. Any supply caches destroyed at the front would be hard for them to make up. Thus, Clark concluded, the communists must have supplies lying in the region beyond UN artillery range but below the bomb line. ${ }^{39}$

It was a brilliant insight and deduction. Subsequent reconnaissance sorties confirmed that the communists had numerous supply facilities, using tunnels or burrowed into hillsides. He immediately arranged for joint USN-USAF strike missions, which were dubbed 'Cherokee strikes' in honour of his Native American ancestry. The Cherokee strike program began in early October 1952. From then until the end of the war, the navy flew an average of three Cherokee missions per day, and night attacks as well. Eighth Army commander General James Van Fleet held the view that if the Cherokee strikes had been coupled with a major UN ground offensive, the NKPA and CPVF forces at the front would likely have fallen back. ${ }^{40}$

Of course, neither side intended to launch massive offensives at this point in the war. Both the Soviet-Chinese partnership and the UN coalition had effectively achieved their major aims: North Korea would not succumb to the South, and South Korea would not succumb to the North. Instead, as other chapters have noted, the fighting was really over positional advantage along the MLR, a battle for local (if strategic) real estate. As an armistice drew nearer, fighting reached a crescendo, and Jocko Clark, as a precaution, journeyed to Tokyo to meet theatre commander General Mark Clark and request that tactical nuclear bombs be placed on TF77's carriers. General Clark concurred, and they were; fortunately, conventional means of waging war continued to carry the day. ${ }^{41}$

On 19 July, word reached FEAF that an armistice was imminent, and on 22 July, FEAF shot down its last MiG. At 10 am on 27 July, a truce was signed, effective later that night. To prevent any last-minute surprises, FEAF flew a maximum effort, putting as many Sabres into the air as it

39 As narrated in J.J. Clark, Carrier Admiral, David McKay Co., New York, 1967.

40 Cagle and Manson, Sea War in Korea, p. 469.

41 Discussed in Clark, Carrier Admiral. 
could over North Korea, one of which caught an Ilyushin Il-12 transport near the Yalu (loaded, as it emerged, with VVS senior officers) and shot it down. Strikes continued along the MLR all day, and UN airmen ceased combat operations as deep night fell over the Korean Peninsula. An uneasy and imperfect peace has remained between North and South Korea to this day.

\section{Conclusion}

Although precise numbers are surprisingly difficult to reconcile across various international data sets, overall, analysis indicates that coalition airmen flew almost 1.2 million sorties - an average, across the war, of more than a thousand sorties per day. ${ }^{42}$ Figure 1 (in the Appendix) offers a perspective on the overall coalition air effort. The armed forces of the United States flew approximately 94 per cent of all these, with other UN airmen flying the remaining 6 per cent. It should be pointed out that while the USAF flew 73 per cent of sorties, US Naval and Marine aviation played a crucially important role, one still not fully appreciated. US Navy and Marine airmen flew 41 per cent of US combat sorties in the Korean War, including 40 per cent of interdiction sorties, 53 per cent of close air support (CAS) sorties, 36 per cent of counter-air (air superiority) sorties and 30 per cent of reconnaissance sorties. Approximately 80 per cent of all combat sorties furnished direct or indirect combat support to Korea's ground warriors: as live fire, ISR (intelligence, surveillance and reconnaissance) or matériel. Although the USAF performance in Korea has been largely seen through the simplistic prism of Sabre versus MiG, and B-29 operations against the North, in fact counter-air sorties accounted for only 14 per cent of all air force combat sorties, and strategic bombing (despite all the publicity surrounding it) not quite a tenth of 1 per cent.

42 Based upon data found in USN, Office of the Chief of Naval Operations, Combat Activity of Naval Aviation (April-July 1953), Table 15, 71, Korean War Naval Aviation Records Collection, Headquarters, Naval History and Heritage Command, Washington Navy Yard, Washington, DC; USAF, USAF Tactical Operations: World War II and Korea (USAF Historical Division Liaison Office, Washington, DC, May 1962), Table 101, 106, 108, 162, Archives of the Air Force Historical Research Agency, Maxwell AFB, AL; R.F. Futrell, The United States Air Force in Korea, 1950-1953 (Duell, Sloan \& Pearce, New York, 1983), p. 690; J.R.P. Lansdown, With the Carriers in Korea: The Fleet Air Arm Story 1950-1953 (Severnside Publishers, Upton-upon-Severn, UK, 1992); and HMAS Sydney patrol reports, May 1951-December 1953, AWM 78, Folders 329/5 and 329/6. 
The relative contribution of all the coalition air forces is shown in Figure 2 (in the Appendix). While deceptively small, the participation of non-USAF coalition air forces had, at various points in the war, a decisive effect all of its own, and often at tremendous cost. The RAAF and South African Air Force, flying with rare dedication and skill, stand out as two air services that materially affected the outcome of the war. The RAAF's No. 77 Squadron established an extraordinary record for the commitment and achievement of its pilots. That record came at a fearful price. The squadron lost 13 Mustangs from the time it entered combat to the time it transitioned into Meteors, then lost a further 46 Meteors from combat and operational losses before the end of the war. Forty of its pilots died, 30 of them in combat, and others were captured and subjected to a brutality that is shocking even by the standards of a later and more jaded world. The steadfastness, courage and performance of the RAAF strengthened further the bonds forged by mutual combat in the Pacific less than a decade previously, and served as a foundation for stronger ties between the United States and Australia in the years ahead. ${ }^{43}$

Finally, there is the legacy of air power in the Korean War itself. Traditionally, armies fear an enemy air force far more than they respect their own. During and after the war, many critics took anti- or pro-air power positions claiming to prove either that it was decisive or that it had failed. In truth, the circumstances of the Korean War shaped the use of air power in important ways. Given the constraints and the sanctuaries, it simply could not be employed in the free-ranging form it had been in the Second World War. That said, while critics since the war have made much of the Manchurian sanctuary, the United Nations had sanctuaries as well, notably Japan and Okinawa. Fortunately, the restrictions placed upon airmen in Korea were far less than those of South-East Asia a decade later.

On balance, the judgement of air power in Korea, and certainly of naval air power in Korea, is that, overall, it worked. It could not be decisive on its own, nor was it expected to be. But thanks to the control of the air that coalition airmen secured, all other tasks in the war were made easier (as Ridgway, Walker, Van Fleet and others amply noted). Beyond question, the tremendous psychological and physical power of air attack over the battlefield prevented, on numerous occasions, the CPVF and NKPA from overwhelming the South and its defenders, as is evidenced

43 The combat record of No. 77 Squadron is well told in Stephens's Going Solo, pp. 225-41. 
by the communications by and among Stalin, Mao, Kim and the commanders and troops of their forces. To that degree, air power certainly fulfilled what was expected of it, and if not overwhelmingly decisive in all applications, it was decisive enough in the most critical phases of the war, consistent with its performance in both earlier and later conflicts. Of air power can be said what the prophet said of old: 'You show your might when the perfection of your power is disbelieved, and in those who know you, you rebuke insolence. ${ }^{.44}$ 
This text is taken from In from the Cold: Reflections on Australia's Korean War, edited by John Blaxland, Michael Kelly and Liam Brewin Higgins, published 2020 by ANU Press, The Australian National University, Canberra, Australia. doi.org/10.22459/IFTC.2019.06 